\title{
Addendum of 2MW Wind Turbine to A Power with Directly-Driven Permanent Magnet Generation System
}

\author{
Dr. Eme, L. C. \\ Department of Civil Engineering, Chukwuemeka Odumegwu Ojukwu University \\ Anambra State, Nigeria \\ E-mail: leeworks2002@yahoo.com \\ Dr. Ulasi, A. J. \\ Department of Electrical/Electronic Engineering, Chukwuemeka Odumegwu Ojukwu \\ University Anambra State, Nigeria \\ E-mail: johnulasi@yahoo.com \\ Engr. AladeTunde A. I. \\ Department of Electrical/Electronic Engineering Nnamdi Azikiwe University Awka \\ Anambra State, Nigeria \\ Dr. Odunze A. C. \\ Diamond International Education Centre, Suite D62 2nd Floor, EFAB Mall Annex, Area 11, Garki, Abuja, \\ Nigeria. \\ E-mail: gieldgreen@gmail.com \\ Ohaji Evans, (B.Eng, M.Eng) \\ Rural Infrastructural Engineer, Implementation Field Office, \\ Niger Delta Support Programme Component, Imo State, Nigeria. \\ E-mail: evansohaji@gmail.com
}

\begin{abstract}
.
In recent years, wind turbine has become an acceptable alternative energy generation, because of the environmental and economic benefits. Notwithstanding more research works still need to be done to reduce wind turbine installation complexity, enhance profitability and reliability especially in developing countries like Nigeria. This paper presents the modeling and analysis of a $2 \mathrm{MW}$ variable-speed directly-driven permanent magnet synchronous generator (PMSG), Wind energy conversion system (WECS). The objective is to optimize the power captured from the wind, ensure optimum efficiency for power generation and reduce system hardware count. The mathematical model for the permanent magnet synchronous wind turbine and its power control algorithms are modified by removing the speed sensors. Further, enhancement was achieved by utilizing wind speed forecasts as the starting speed. A modified Field Orientation Control FOC and voltage orientation control VOC scheme were developed for the system using matlab Simulink CAD application. The Simulation results of the model for various changes in wind speed utilizing average wind speed data of Mmaku in Awgu local government area of Enugu state Nigeria. The developed system ability to 'smoothen' the power, voltage output and operates at the optimum coefficient of performance between the cut in speed of $3 \mathrm{~m} / \mathrm{s}$ and $12 \mathrm{~m} / \mathrm{s}$ without wind sensor is found to be promising,
\end{abstract}

Key words: wind turbine, variable-speed, permanent magnet, synchronous generator, efficiency

DOI: $10.7176 / \mathrm{JETP} / 9-3-04$

Publication date:March $31^{\text {st }} 2019$

\subsection{Introduction}

The African Development Bank (AfDB) estimated Nigeria electricity supply par capita from the national grid to be less than $0.8 \mathrm{kwh}$ and below $50 \%$ access in 2009 from $151.3 \mathrm{kWh} /$ capita and $67 \%$ access in 2000 . This is against the estimated par capita of $1416.87 \mathrm{KwH}$ and $95 \%$ access to public power supply based on country with similarity in terms of education and lifestyle (Olanyande,J.S.\&Rogo,2010). Energy is an essential input for economic growth; the lack of electricity restricts the development of all aspects of a normal modern life style. Nigeria, the most populous Black Country of the world, has experienced hampered economic and industrial growth primarily on account of in adequate and inefficient electricity generation and supply systems.

On the contrary Nigeria is blessed with evenly distributed and abundant renewable energy resources such as waterfalls that can power small hydro dams, an average 10hours daily annual average sun shine period and estimated wind speed of over $3 \mathrm{~m} / \mathrm{s}$ to $17 \mathrm{~m} / \mathrm{s}$ increasing from south to north (above the projected cut in speed of 
$2.5 \mathrm{~m} / \mathrm{s}$ for most turbines) (Illojeo. 2004). Renewable energy has the advantages that it is abundant, clean, and becoming increasingly economical. Infact, renewable energy sources help in reducing about 70 million metric tons of carbon emissions per year that would have been produced by fossil fuels (U.S. green house gas emissions, 2007)

Most of the wind turbines applied in industry is variable-speed wind turbines. Among various types of variables peed WECSs, three kinds are most widely applied in industry:

(i) Doubly-fed induction generator (DFIG) WECSs with reduced-capacity power converters. (ii) Geared/gearless quirrel-cage induction generator (SCIG) WECSs with full-capacity power converters. (iii) Geared/gearless Wound-Rotor Synchronous Generator (WRSG)/ Permanent Magnet Synchronous Generator (PMSG) WECSs with full-capacity power converters (B.Wu Y. L.,2011).

Large scale wind turbines (up to 10MW) seems to attracts more and more research attention, the direct-drive PMSG based WECSs which are very suitable for large scale wind plants have become a "trending topic". The direct-drive wind turbine PMSGs does not have the gear box between the wind turbine and the PMSG rotor shaft, thus avoids the mechanical power losses caused by the gear box. Further more, the removal of the gear box also helps in reducing the cost of the system.

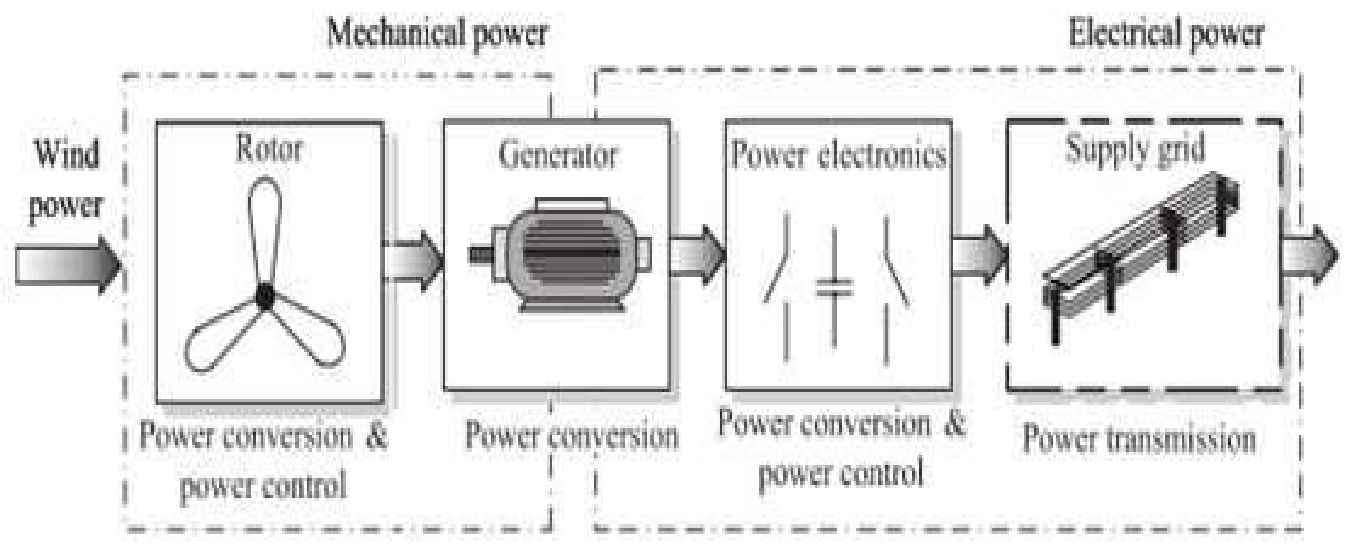

Figure 1.1 System configuration of the direct drive wind

The overall configuration of a direct-drive wind turbine PMSG system is shown in Figure

1.4. From this figure, this system is composed of a wind turbine PMSG, a rectifier, and an inverter. The wind turbine PMSG transforms the mechanical power from the wind into the electrical power, while the rectifier converts the AC power into DC power and controls the speed of the PMSG. The controllable inverter helps in converting the DC power to variable frequency and magnitude AC power. With the voltage oriented control VOC algorithm, the inverter also possesses the ability to control the active and reactive powers injected into the grid.

In control of direct-drive PMSG systems, the information of the rotor position and Speed is needed to implement the advanced control algorithms such as the field oriented control (FOC) and direct torque control (DTC). Conventional methods to acquire the rotor position and speed information are based on an encoder or a transducer mounted on the rotor shaft. However, such electrical speed sensors increase the hardware count, complexity and system cost. In addition, the rotor mounted sensors have to endure the constant oscillations of the rotor shaft, which reduces the reliability of the system. Speed sensor failures cause more than $14 \%$ of failures in such WECSs (Bertling,2005). The malfunction of the speed sensor will cause the breakdown of the whole system, which will contribute to considerable losses in power production. Additionally, the repair of the failed components results in increase operational cost.

Furthermore, wind speed measurements as a control variable can make the system un-reliable and can lead to considerable trouble (Hau,2006). Usually, the wind speed is measured on the nacelle roof, and the wind speed upstream is estimated. This method of wind measurement shows a discrepancy of 2 to $3 \mathrm{~m} / \mathrm{s}$ (Hau,2006). The accuracy of these measurement devices is about $\pm 2 \%$ and they are very sensitive to the air flow around then 
acelle. The time response of the anemometer is also large compared to the electrical system's response. Anemometers generate an electrical signal from a rotating spindle, and then the signal is sent to the controller. Nevertheless, the best representation of the wind speed is the rotor power. In an ideal system the rotor power will be equal to the electric power, thus by measuring the electric power we will be able to determine the wind speed, control the wind turbine and make the system more reliable. Further improvement is possible by utilizing wind speed forecast value as the starting or estimated speed. This will in turn reduce considerably the system iteration time and facilitate fast convergence. Based on the mentioned issues, this work proposes a back EMF based rotor position and modified sensor less control approach.

In this work a models for the permanent magnet synchronous wind turbine are evaluated and modified optimal power control system model is developed with intension to control a variable speed wind turbine to maximize the power extraction from the wind. This work: (i) computes expected maximum power based on metrological forecast of the wind speed, and select most appropriate blade angle or $\lambda$ (ii) calculates the rotor position based on same (iii) The electric power, Ac voltage ( $\left.V_{a b c}\right)$ and current ( $\left.I_{a}, b, c\right)$ components of the PMGS is modeled to estimate the wind speed and rotor angle in six iteration cycle per second (6hz.). These two variables are compared with the calculated (reference value) and measured value and discrepancies feedback into the controller until both measurement converges (optimized) without wind speed sensor. (iv) The developed model performance is tested on matlab Simulink for efficiency. Enugu is situated at $6.44^{\circ}$ North latitude, $7.49^{\circ}$ East longitude and 248 meters elevation above the sea level. (Most complex maps for all cities in the world, 2015). The State occupies much of the high lands of Awgu, Udi and Nsukka Fig 1.5 Area view of coal mine Enugu.

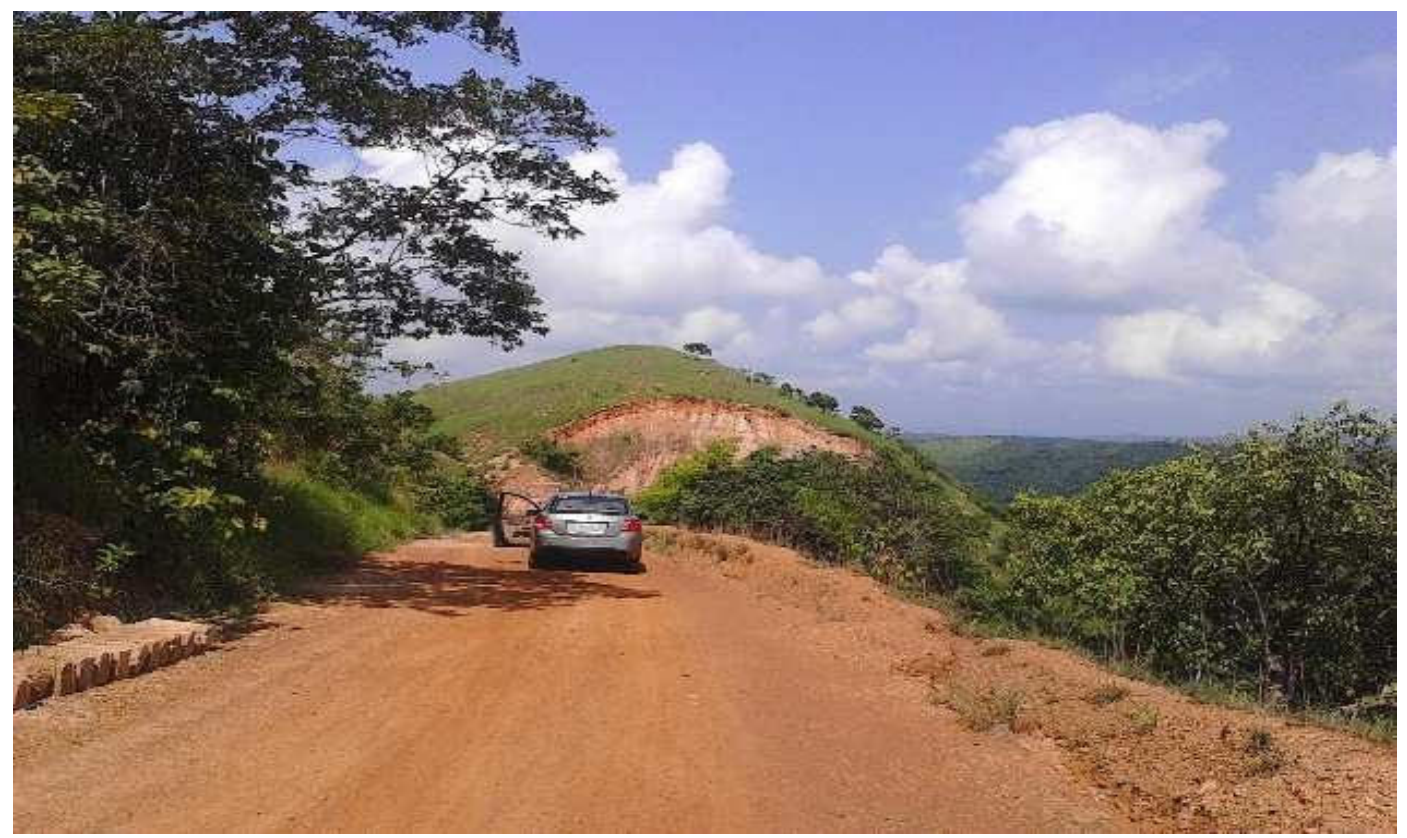

Figure 1.2 Area view of Mmaku hill, Awgu

The hills are 300 to1,000 metres (3,300ft) above sea level, and are flanked by the rolling low lands of border towns (Egboka,1985). This offers ideal site for installation of wind turbine due to reduction of in-wind turbulence and higher wind speed at the elevated plains. Therefore, Mmaku in Awgu Local Government Area, Enugu is chosen as test study site in this work.

\subsection{Methods:}

Synchronous machines are Ac rotating machines that rotate at a speed proportional to the armature current frequency. In this type of machine the magnetic field created by the armature currents rotate at the same speed as that created by the field current on the rotor. Synchronous machines have been used for many 
years as generators of large power plants such as turbine generators and hydroelectric generators. These synchronous generators are normally used at constant speed and are connected directly to the electric grid. For variable speed applications permanent magnet synchronous machine (PMSM) are used and are quickly becoming the next-generation variable speed Ac motor drives due to the availability of high-energy permanent magnet materials. The PMSM has widely found its application as a high performance machine drive because of the ripple free torque characteristics and simple control strategies. Compared to induction machine drives, the PMSM has less rotor losses hence, it is potentially more efficient. In addition, the PMSM can achieve higher torque densities than its wound rotor counterpart.

Permanent magnet synchronous machines have lower reactance values than their equivalent rotor wound machines. In addition, PMSM are more power dense than their rotor wounded counter parts and they can provide full rotor flux at all times. Due to these characteristics, permanent magnet synchronous generators (PMSG) have high peak torque capabilities that would be beneficial to a wind turbine system during wind gust. These machine scan also resist repetitive torque pulsations of up to $20 \%$ of the rated torque ( Bhadra,2005).For EMF and estimation of the rotor position and speed, David (1999), Spurpeon (1998)\& Kang (2004)

\subsection{Modeling of Control Scheme of WECS}

In this session, the mathematical models of the wind turbine and the PMSG is developed and analyzed. These further deepens the understanding of the control modeling for the generator and grid side control system. Modeling is a basic tool for engineering analysis, such as: project optimization, design and control. Wind energy conversion systems are very different in nature from conventional generators, and therefore dynamic studies must be addressed in order to integrate wind power into the power system. Mathematical models utilized for steady-state analysis are extremely simple, while the dynamic models for wind energy conversion systems are not easy to develop. Dynamic modeling is needed for various types of analysis related to system dynamics: stability, control system and optimization.

\subsubsection{Wind Turbine Aerodynamic Model}

The main components of a direct-drive permanent magnet synchronous generator (PMSG) wind turbine are the wind turbine and the PMSG. The wind turbine captures the power from the wind for the system, and the PMSG transforms the mechanical power into electric power.

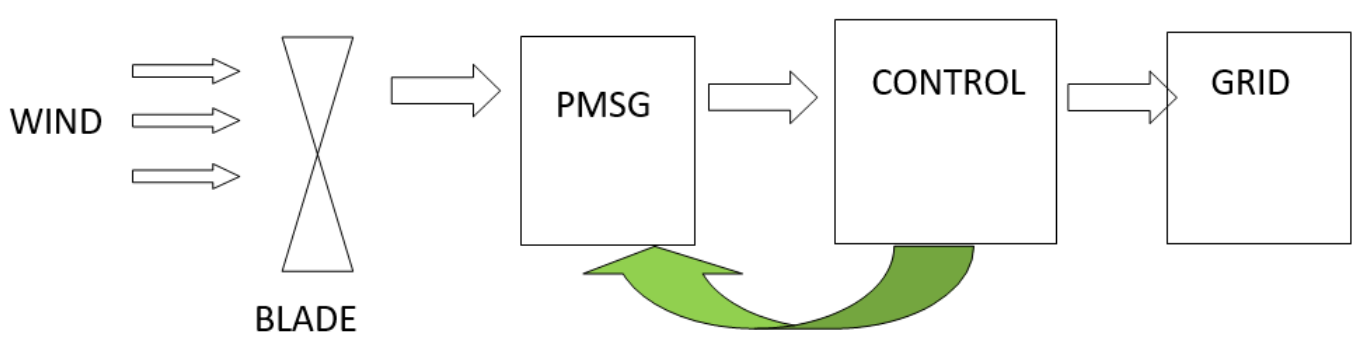

Figure 2.1 WEC Control System Block Representation

In order to investigate the effectiveness so the energy conversion in wind energy conversion systems WECS, first the available energy stored in the wind needs to be determined. The energy in the wind can be treated as the kinetic energy of a large amount of air particles with. A total mass, $\mathbf{m}$, moving at a wind velocity, $\mathbf{V}_{\text {air. }}$ Assuming that all the air particles are moving at the same speed and direction before impacting the rotor blades of the wind turbine, the potential available (kinetic energy stored) in the wind can be expressed according to the following expression:

$$
\mathbf{E}=1 / 2 \mathbf{m} \mathbf{V}^{2} \text { air }
$$

Where, E, is the kinetic energy of the moving air particles, and the total mass of the air particles, while, $\mathbf{V}_{\text {air, }}$, is the velocity of the air particles (wind speed). Since the air particles are moving at a speed, $\mathbf{V}_{\text {air, }}$, the total mass, $\mathrm{M}$, of the particles for a period of time, $\mathrm{t}$, can be rewritten as follows: 


$$
\begin{aligned}
\mathrm{m} & =\rho x A x V_{\text {air }} \mathrm{xt} \\
& =\rho \pi \mathrm{r}^{\&} \mathrm{~V}_{\text {air }}{ }^{\mathrm{t}}
\end{aligned}
$$

Were, $\rho$. Is the air density, and A is the swept area of the wind turbine rotor. Here, $r$, is the radius of the wind turbine rotor.

\subsection{Results and Discussion}

In this section the simulation model of the wind turbine is implemented. Fig. 2.1 shows the complete system model diagram in which each block represents a sub-system of the system. There is a mathematical model for each sub system. In the previous section model and power capacity of the wind turbine, the generator, the dcto-dc converter and dc-to-ac inverter was simulated.

\subsection{Wind Turbine Model}

The amount of power that a wind turbine can extract from the wind depends on the turbine design. Factors such as the rotor diameter and the wind speed affect the amount of power that a turbine can extract from the wind. The wind turbine was modeled using the mathematical equations shown in session 2. Table 3.1 shows the average recorded wind speed at $180 \mathrm{~m}$ above sea level used in simulation model and table 3.2 shows the power capacity and parameters of the wind turbine.

\subsection{Electrical System Model}

The electrical system is formed by the permanent magnet machine, a passive rectifier, a dc-to - dc converter and a voltage source inverter. In the following section the electric machines parameters, the components of the electrical system and the simulation model of the electrical systems is shown. The value of the elements for the $\mathrm{dc}-$ to $-\mathrm{dc}$ converter and the inverter dc bus side were obtained using the design equations given in session 2.

\subsection{Control Simulation Model}

The model for the maximum power tracking algorithm and the dc-to-dc controller are shown in Fig. 3.4.The embedded MATLAB function contains the mathematical model that represents the maximum power tracker and developed PMSG control model. The triggered is set at a frequency of $10 \mathrm{~Hz}$; therefore running algorithm 6 times per second. Every time the model is run the power is calculated from projected wind speed and the controller reacts to the reference voltage commanded by the maximum power tracker. The generated EMF is compared with calculated and the difference is applied to MPPT in subsequent iteration. The inverter controller has two feedback loops, the generator side loop control the dc side voltage of the PMSG and the grid loop controls the active power injected into grid. 
Table 3.2 Parameters and Operating Conditions of the Generator Side Control System (Vestas Wind Systems A/S,2014)

\begin{tabular}{|c|c|c|}
\hline $\mathrm{S} / \mathrm{N}$ & Technical specifications & Operational data \\
\hline 1 & Rated power & $2,000 \mathrm{~kW}(50 / 60 \mathrm{~Hz})$ \\
\hline $\mathrm{zz} 2$ & Cut-in wind speed & $3 \mathrm{~m} / \mathrm{s}$ \\
\hline 3 & Rated wind speed & $11.5 \mathrm{~m} / \mathrm{s}$ \\
\hline 4 & Cut-out wind speed & $20 \mathrm{~m} / \mathrm{s}$ \\
\hline 5 & Wind class & IECIIIA \\
\hline 6 & $\begin{array}{l}\text { Operating temperature range standard turbine } \\
-\end{array}$ & $20^{\circ} \mathrm{Cto} 40^{\circ} \mathrm{C}$ \\
\hline 7 & $\begin{array}{l}\text { Operating temperature range low temperature } \\
\text { turbine }\end{array}$ & $-30^{\circ} \mathrm{Cto} 40^{\circ} \mathrm{C}$ \\
\hline & SOUND POWER & Max $107.5 \mathrm{~dB}$ \\
\hline \multirow[t]{2}{*}{1} & \multicolumn{2}{|c|}{ (Mode $0,10 \mathrm{~m}$ above ground, hub height $80 \mathrm{~m}$, air density $1.225 \mathrm{~kg} / \mathrm{m}^{3}$ ) } \\
\hline & \multicolumn{2}{|c|}{ Rotor } \\
\hline 1 & Rotor diameter & $110 \mathrm{~m}$ \\
\hline 2 & Sweptarea & $9,503 \mathrm{~m} 2$ \\
\hline \multirow[t]{2}{*}{3} & $\begin{array}{l}\text { Airbrake full blade feathering with } 3 \text { pitch } \\
\text { cylinders }\end{array}$ & \\
\hline & \multicolumn{2}{|c|}{ Electrical } \\
\hline 1 & Frequency & $50 / 60 \mathrm{~Hz}$ \\
\hline 2 & Generator type 4- pole, PMS generator & $(50 \mathrm{~Hz}) /$ \\
\hline \multirow[t]{3}{*}{3} & Generator type 6-pole,slip rings & $60 \mathrm{~Hz}$ \\
\hline & Gearbox & $\begin{array}{l}\text { Type two planetary stages and } \\
\text { One helical stage }\end{array}$ \\
\hline & Tower & \\
\hline 1 & Type & Tubular steel tower \\
\hline \multirow[t]{3}{*}{2} & Hub heights & $95 \mathrm{~m}$ and $125 \mathrm{~m}(50 \mathrm{~Hz})$ \\
\hline & & $80 \mathrm{~m}$ and $95 \mathrm{~m}(60 \mathrm{~Hz})$ \\
\hline & Blade dimensions & \\
\hline 1 & Length & $54 \mathrm{~m}$ \\
\hline 2 & Max. Chord & $3.9 \mathrm{~m}$ \\
\hline \multicolumn{2}{|c|}{ Rated Mechanical Torque } & $848826 \mathrm{Nm}$ \\
\hline \multicolumn{2}{|c|}{ Rated Rotor Flux Linkage } & $5.8264(\mathrm{rms})$ \\
\hline \multicolumn{2}{|c|}{ Stator Winding Resistance } & $0.821 \mathrm{~m} \Omega$ \\
\hline \multicolumn{2}{|c|}{$D$ axis Synchronous Inductance } & $1.5731 \mathrm{mH}$ \\
\hline \multicolumn{2}{|c|}{$Q$ axis Synchronous Inductance } & $1.5731 \mathrm{mH}$ \\
\hline \multicolumn{2}{|c|}{ Wind Turbine Rotor Radius } & $34 \mathrm{~m}$ \\
\hline \multicolumn{2}{|c|}{ Wind Turbine Optimal Tip Speed Ratio } & 6.16 \\
\hline \multicolumn{2}{|c|}{ IGBT Modulation Frequency } & $1.5 \mathrm{kHz}$ \\
\hline
\end{tabular}




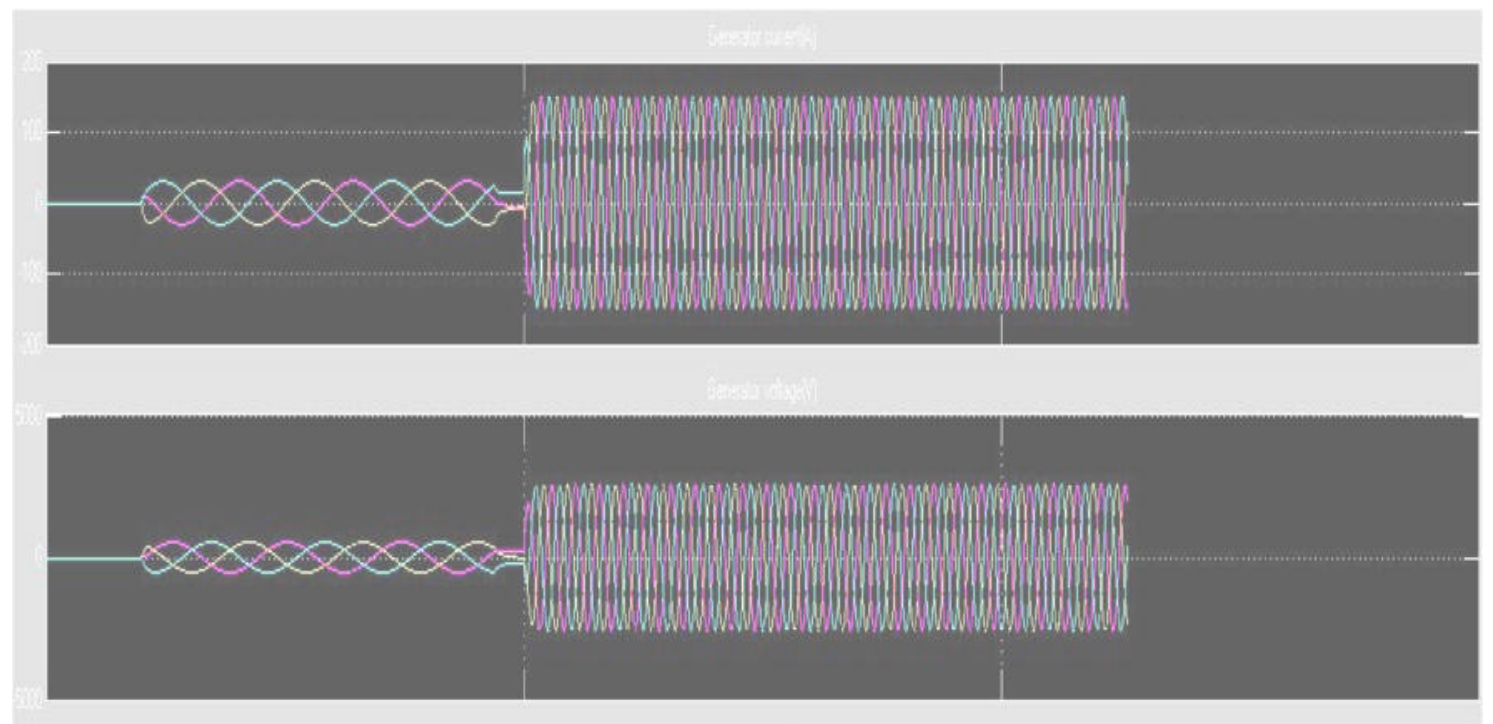

Figure 3.1 Generator current and voltage output waveform
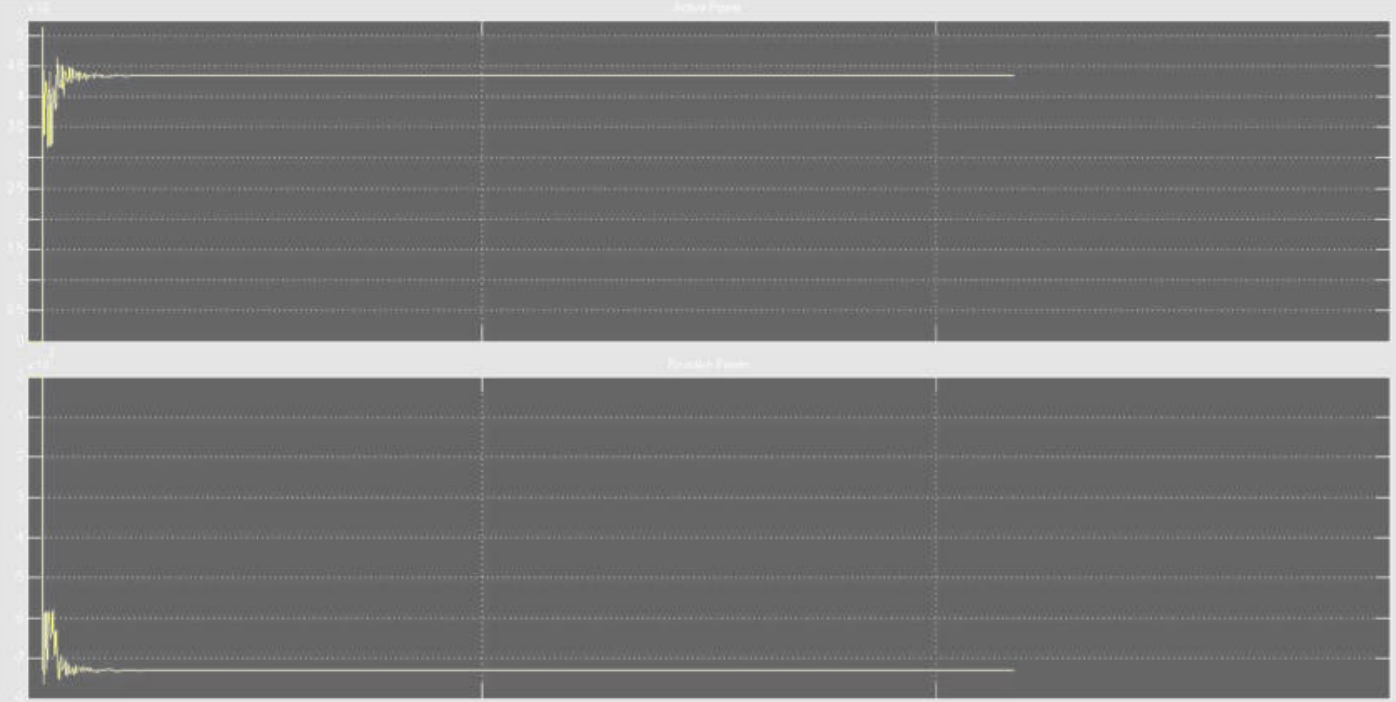

Figure 3.2 Wind speed \& power (kw) output wave form 


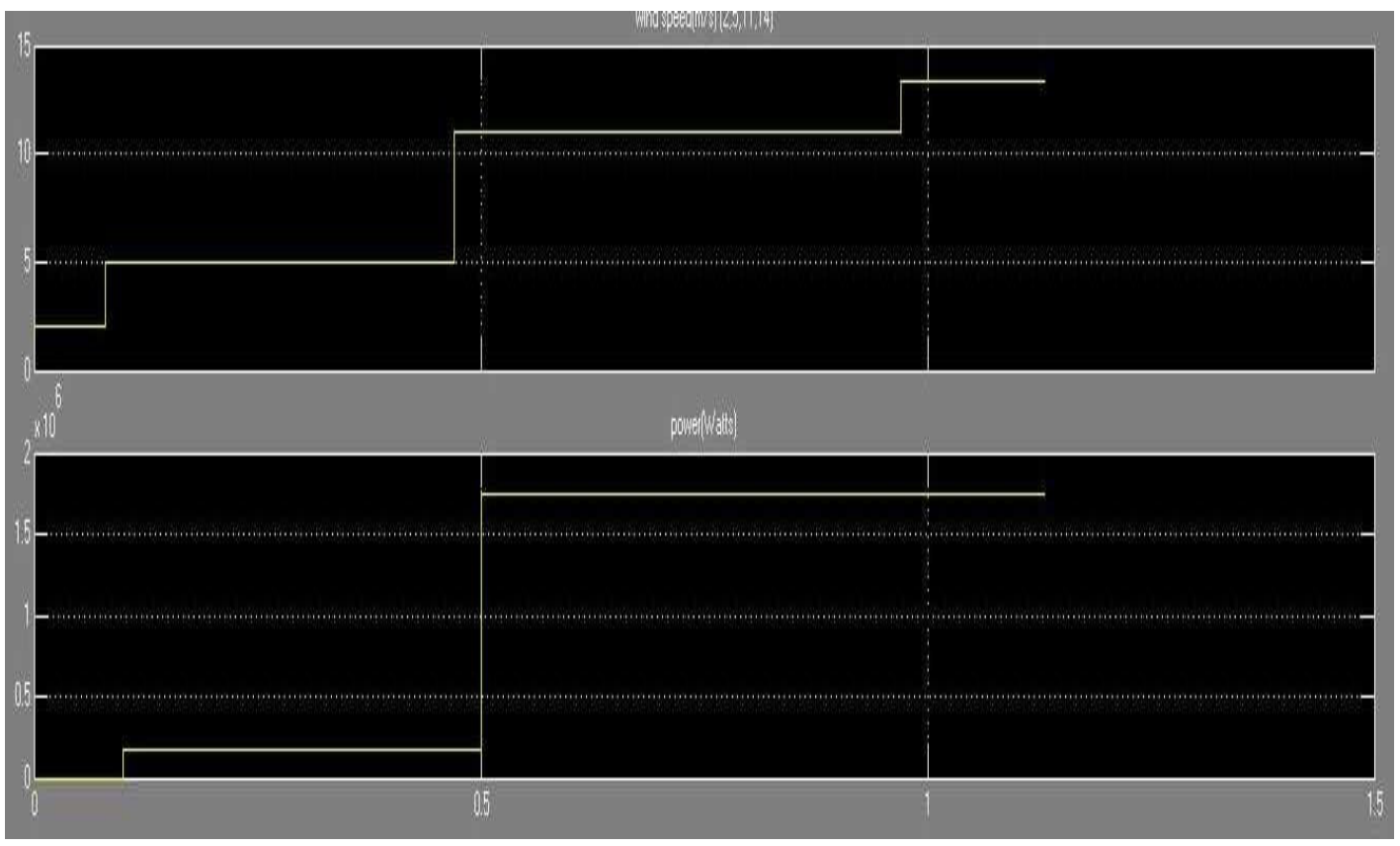

Figure 3.3: Active and output wave form

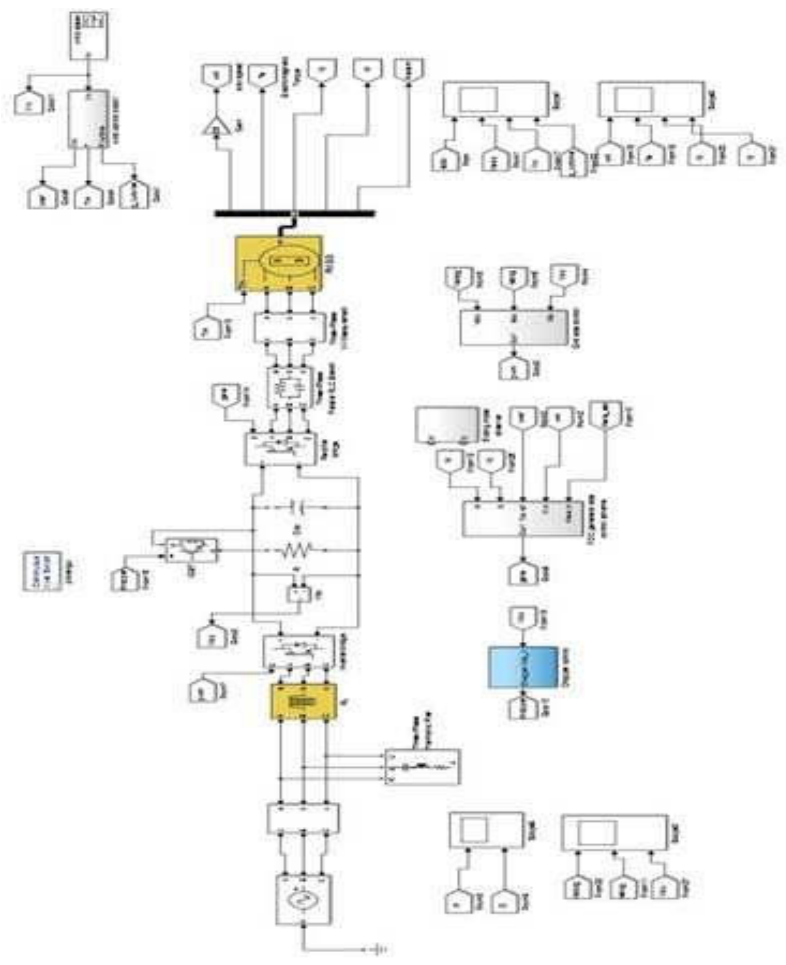

Figure 3.4 .Matlab power system model 


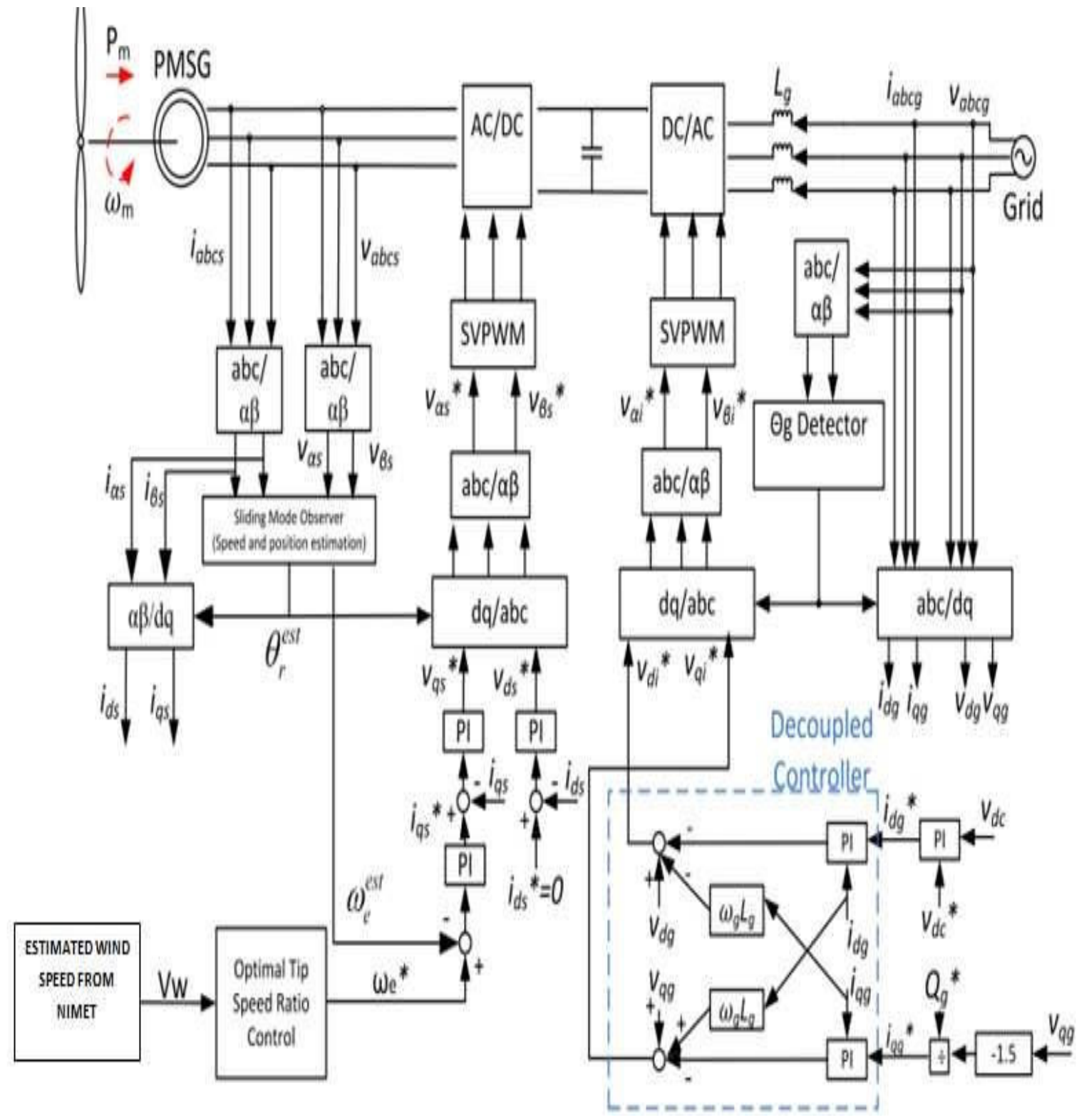

Figure 3.5. Control scheme of the wind turbine generation system including the sliding mode

observer

\subsection{Conclusions}

This work has presented and analyzed modified sensor less control algorithms for the wind turbine PMSG systems. This control methods is further validated by its application by simulation to a case study of $2 \mathrm{MW}$ wind turbine PMSG system. A simulation study was performed for generator-side converter control, the MPPT control algorithm and vector control method were applied. The simulation results shows capability of the modified sensor less model to control: the MPPT, PMSG to generate the maximum power at $3 \mathrm{~m} / \mathrm{s}$ to $12 \mathrm{~m} / \mathrm{s}$ typical meteorological wind speeds of Enugu state. We observed high dynamic performance of the vector control method when the wind speed changed, the generator speed which was controlled by the vector control algorithm reacted to the wind speed change very fast. Thus, for the wind turbine PMSG systems that require high dynamic performance and high power capture efficiency, the modified model of FOC and vector control algorithms were proven to be efficient. It also shows good control of VOC algorithm; its capability to control the active power and reactive 
power injected into the grid easily with high dynamic performance. Our developed modified sliding mode observer based PMSG rotor position and speed self- sensing control applied to the system also show a lot of superiority. The simulation results indicated that the estimated rotor position and speed correspond to their actual values very well.

\section{References}

Akinlade,G.a.(2012).Investigation of Power Law Wind Exponent Within The Lower Boundary Layer at Ile-Ife, Nigeria. Ife Journal of Science, Vol.14(No.2),325-335. Alvarez

Bertling,J.R.(2005). Survey of Failures in Wind Power Systems with Focus on Swedish Wind Power Plants During 1997.22(No.1).

Bhadra,S.N.D.K.(2005).Wind Electrical Systems. Oxford, UK: Oxford University Press. Blaabjerg,F.M.L.(2012).Power Electronics Converters for Wind Turbine Systems.48,No.2 (Pp708-719).

David,K. \&Young,V.I.(1999). A Control Engineer's Guide to Sliding Mode Control. Vol.7 (No.3).

Egboka,B.C.(1985).Water Resources Problems in the Enugu Area of Anambra State, Nigeria. WREPU Department of Geological Anambra State University of Technology, pp.95,97

H.Li,K.S.(2005). Neural-Network-Based Sensorless Maximum Wind Energy Capture with Compensated Power Coefficient. IEEE Transactions on Industry Applications, Vol.41, No.6,Pp.1548-1556,.

Hau,E.(2006).Wind Turbines: Fundamentals, Technologies, Application ,Economics, 2nd Edition. Berlin, Germany: Springe.

Huang, M.C.A.J.(2006). The Comparison of Sensorless Estimation Techniques for PMSM Between Extended Kalman filter and Flux-Linkage Observer .IEEE Conference and Exposition in Applied Power Electronics.

Huang, N.(2013) Simulation of Power Control of a Wind Turbine Permanent Magnet Synchronous Generator System. Retrieved from epublications.marquette.edU: http://epublications.marquette.edu/theses_open/215

Illojeo,C.(2004).Overview of Renewable Energy Solutions and Development of Master Plant for Rural Communities in Nigeria Energetic Solution. Abuja/Calabar: Energy Commission of Nigeria.

Kang, K.J.K.(2004). Sensorless Control of PMSM in High Speed Range with Iterative Sliding Mode Observer. In Conf. Rec. IEEEAPEC.

Most Complex Maps for all cities in the World (2015).Enugu Road Map, Enugu Terrain Map, Enugu Satellite View. Retrieved from www.maps-streetview.com:www.maps-streetview.com/Nigeria/Enugu/

Spurpeon, C.E. (1998).Sliding Mode Control: Theory and Applications. New York: Taylor \& Francis.

U.S. Green House Gas Emissions.(2007). Wind Energy Hand Book. Retrieved April 02, 2015, from http://www.ornl.gov:http://www.ornl.gov/climate_change/climate.htm,

Vestas Wind Systems A/S. (2014). Hedeager 44. 8200A arhus N. Denmark.

Wikipedia.(2015).https://en.wikipedia.org.Retrieved September 15, from en.wikipedia:

https://en.wikipedia.org/wiki/Darrieus_wind_turbine

Wu, B. (2006). High-Power Converters and AC Drives. Wiley-IEEE Press.

Wu,B.Y.L.(2011). Power Conversion and Control of Wind Energy Systems. Hoboken, NJ: Wiley.

Wu,R.A.(1991). A Permanent Magnet Motor Drive without A Shaft Sensor.Vol.27, No.5, (Industry Applications). 